Bangladesh J. Bot. 48(2): 223-229, 2019 (June)

\title{
EFFECTS OF SODIUM HYPOCHLORITE ON SOME PHYSIOLOGICAL AND CYTOGENETICAL PARAMETERS IN ALLIUM CEPA L. EXPOSED TO SALT STRESS
}

\author{
Kürşat ÇavuşoĞlu* ${ }^{*}$ Fadime DoĞu and Dilek ÇavuşoĞlu ${ }^{1}$ \\ Department of Biology, Faculty of Arts and Science, Süleyman Demirel University, \\ 32260-Isparta, Turkey
}

Keywords: Sodium hypochlorite, Physiological parameters, Chromosomal aberration

\begin{abstract}
The effects of sodium hypochlorite $(\mathrm{NaClO})$ on the seed germination, seedling growth (radicle length, radicle number and fresh weight), mitotic activity and chromosomal aberrations of Allium cepa L. germinated under salt stress were studied. Salt stress considerably inhibited the seed germination and seedling growth of A. сера. Furthermore, it markedly reduced the mitotic index in root tip meristems of the seeds and increased the number of chromosomal aberrations. Whereas, the detrimental effects of salt on the seed germination, seedling growth, mitotic activitiy and chromosomal aberrations were dramatically alleviated in varying degrees by $\mathrm{NaClO}$ application.
\end{abstract}

\section{Introduction}

Accumulation of excess salts in the root zone resulting in a partial or complete loss of soil productivity is a worldwide phenomenon. Approximately $20 \%$ of the world's cultivated land, which account for over $6 \%$ of the world total area, is threatened by salinity (Fao 2015). The salt affected soils contain excess salts which affect plants by decreasing the osmotic potential of the soil solution (osmotic stress), interfering with normal nutrient uptake, inducing ionic toxicity and associating nutrient imbalances (An et al. 2003). Processes such as seed germination, seedling growth and vigour, vegetative growth, flowering and fruit set are adversely affected by high salt concentration, ultimately causing diminished economic yield and also quality of production (Sairam and Tyagi 2004).

Sodium hypochlorite is frequently used as a disinfectant or a bleaching agent, which releases oxygen gas as a by-product and is highly effective against all kinds of bacteria, fungi and viruses, by oxidizing biological molecules such as proteins and nucleic acids (Bewley and Black 1994). The effects of $\mathrm{NaClO}$ on the seed germination and seedling growth are conflicting. Thus, $\mathrm{NaClO}$ has been reported to either promote (Vujanovic et al. 2000) or inhibit (Ilahi and Hussain 1988) the germination and growth. Although there are many reports about the effects of $\mathrm{NaClO}$ on the seed germination and seedling growth under normal conditions (Nwangburuka et al. 2012, Varasteh et al. 2015), the protective mechanisms of $\mathrm{NaClO}$ on salt stress in plants is still unknown. The present study was designed to examine the influence of $\mathrm{NaClO}$ in reducing the detrimental effects of salt stress on the seed germination, seedling growth, mitotic activity and chromosomal aberrations of Allium cepa L.

\section{Materials and Methods}

Germination of seeds of Allium cepa L. was carried out using $0.225 \mathrm{M} \mathrm{NaClO}$ at a constant temperature $\left(20^{\circ} \mathrm{C}\right)$, in the dark in an incubator. Healthy and approximately equal-sized $A$. cepa seeds were selected. The seeds were sterilized with $2.5 \%$ sodium hypochloride solution for $10 \mathrm{~min}$

*Author for correspondence: <kursatcavusoglu@sdu.edu.tr>, <kursat16@gmail.com>. Department of Food Processing, Atabey Vocational School, ${ }^{1}$ Isparta University of Applied Sciences, 32670-Isparta, Turkey. 
and washed for $24 \mathrm{hrs}$ in ultra-distilled water. Twenty seeds from each treatment group were placed into the plastic containers. The seeds were divided into four groups: Group I (control) was treated with distilled water for 7 consecutive days. Group II was treated with $0.225 \mathrm{M} \mathrm{NaCl}$ alone for 7 consecutive days. Group III was treated with a $0.1 \% \mathrm{NaClO}$ for 7 consecutive days. Group IV was treated with a $0.1 \% \mathrm{NaClO}+0.225 \mathrm{M} \mathrm{NaCl}$ for 7 consecutive days. Plastic containers were placed into an incubator for germination. It was assumed that the radicle should be $10 \mathrm{~mm}$ long for germination. At the end of the $7^{\text {th }}$ day, after determination of the final germination percentages, radicle numbers were also recorded, and radicle lengths of the seedlings were measured in $\mathrm{mm}$ and in addition, the fresh weights in $\mathrm{g} /$ seedling were determined. All experiments were repeated 3 times.

After several days, root tips of germinated A. серa were excised $(1-1.5 \mathrm{~cm}$ segment) for cytogenetic analysis. Then, they were pretreated with saturated para-dichlorobenzene for $4 \mathrm{hrs}$, fixed in solution of ethanol: acetic acid $(3: 1)$ overnight at room temperature and stored at $4^{\circ} \mathrm{C}$ in $70 \%$ ethanol until used. The root tips were hydrolysed in $1 \mathrm{~N} \mathrm{HCl}$ at $60^{\circ} \mathrm{C}$ for $15 \mathrm{~min}$, stained with Feulgen for $1-1.5 \mathrm{hrs}$, smashed in a drop of $45 \%$ acetic acid and squashed. After $24 \mathrm{hrs}$, microscopic slides were made permanent by mounting in balsame. The mitotic phases and mitotic aberrations were photographed (100X) with a digital camera (Olympus C-5060) mounted on an Olympus CX41 microscope.

Mitotic index, i.e. percentage of dividing cells scored was evaluated by analysing at least 30.000 cells per treatment (approx. 10.000 per slide). Chromosomal abnormalities were calculated for each concentration as the percentage of 2000 dividing cells counted. Statistical evaluation of all parameters was made by using SPSS program according to DMRT.

\section{Results and Discussion}

As shown in Table 1, the radicle length, radicle number and fresh weight of the group III seeds germinated in the medium with $\mathrm{NaClO}$ alone reduced as compared to ones of the group I (control) seeds germinated in distilled water medium while their germination percentage was statistically the same as ones of the group I seeds (Table 1). There are enough studies about the effects of $\mathrm{NaClO}$ on the seed germination and seedling growth under normal conditions. However, from these studies, no conclusion could be reached. Thus, $\mathrm{NaClO}$ has been reported to promote (Vujanovic et al. 2000, Varasteh et al. 2015), inhibit (Ilahi and Hussain 1988) or be ineffective (Nwangburuka et al. 2012) the seed germination and seedling growth. These differences of observations may have resulted from differences in treatment times, concentrations used and plant species (Mendes de Jesus et al. 2016).

Salt exhibited an inhibitive effect on all examined growth parameters. For example, the group I (control) seeds germinated in distilled water medium displayed $100 \%$ germination on the $7^{\text {th }}$ day while this value became $25 \%$ in the group II seeds germinated in $0.225 \mathrm{M}$ salinity. In other words, salt prevented $75 \%$ the germination of A. cepa seeds. Salt stress can perform its preventive effect in many ways. It may interfere with seed germination by changing the water status of the seed so that water uptake is inhibited. The present results showing the decrease in the fresh weight and water content of the seedlings in saline medium may be explained by the failure of the roots to receive sufficient water due to the high osmotic pressure of the medium. The inhibitive effect of salt on the radicle length and radicle number may result from reducing cell division, nucleic acid and protein synthesis.

$\mathrm{NaClO}$ application markedly alleviated the inhibitive effect of salt stress on the seed germination. The group IV seeds treated with $\mathrm{NaClO}$ showed $98 \%$ germination. Finally, A. cepa seeds showed a performance such as germinated under normal conditions, are not in saline conditions (Fig. 1). NaClO also continued its success on the seedling growth parameters such as 
the radicle length, radicle number and fresh weight. The radicle length, radicle number and fresh weight of the group II seedlings grown in $0.225 \mathrm{M}$ salinity were $10.4 \mathrm{~mm}, 16.8$ and $12.3 \mathrm{~g}$, respectively while these values were $33.5 \mathrm{~mm}, 34.1$ and $13.2 \mathrm{~g}$ in the group IV seedlings treated with $\mathrm{NaClO}$ (Table 1). There are a few studies which examined effects of $\mathrm{NaClO}$ on the seed

Table 1. Effect of NaClO on some growth of Allium cepa.

\begin{tabular}{lcccc}
\hline \multirow{2}{*}{ Groups } & \multicolumn{4}{c}{ Growth parameters } \\
\cline { 2 - 5 } & $\begin{array}{c}\text { Germination } \\
(\%)\end{array}$ & $\begin{array}{c}\text { Radicle length } \\
(\mathrm{mm})\end{array}$ & $\begin{array}{c}\text { Radicle } \\
\text { number }\end{array}$ & $\begin{array}{c}\text { Fresh weight } \\
(\mathrm{g} / \text { seedling})\end{array}$ \\
\hline Group I & $* 100 \pm 0.0^{\mathrm{b}}$ & $75.2 \pm 1.0^{\mathrm{d}}$ & $48.5 \pm 1.4^{\mathrm{d}}$ & $17.7 \pm 0.7^{\mathrm{c}}$ \\
Group II & $25 \pm 0.0^{\mathrm{a}}$ & $10.4 \pm 0.2^{\mathrm{a}}$ & $16.8 \pm 1.1^{\mathrm{a}}$ & $12.3 \pm 1.2^{\mathrm{a}}$ \\
Group III & $100 \pm 0.0^{\mathrm{b}}$ & $53.2 \pm 0.2^{\mathrm{c}}$ & $42.8 \pm 1.8^{\mathrm{c}}$ & $14.4 \pm 1.1^{\mathrm{b}}$ \\
Group IV & $98 \pm 2.8^{\mathrm{b}}$ & $33.5 \pm 1.0^{\mathrm{b}}$ & $34.1 \pm 1.9^{\mathrm{b}}$ & $13.2 \pm 0.1^{\mathrm{ab}}$ \\
\hline
\end{tabular}

*The difference between values with the same letter in each column is not significant at $0.05( \pm \mathrm{SD})$. Group I (control) was treated with distilled water; group II was treated with $0.225 \mathrm{M} \mathrm{NaCl}$ alone; group III was treated with a $0.1 \%$ dose of $\mathrm{NaClO}$; group IV was treated with a $0.1 \%$ dose of $\mathrm{NaClO}+0.225 \mathrm{M} \mathrm{NaCl}$.

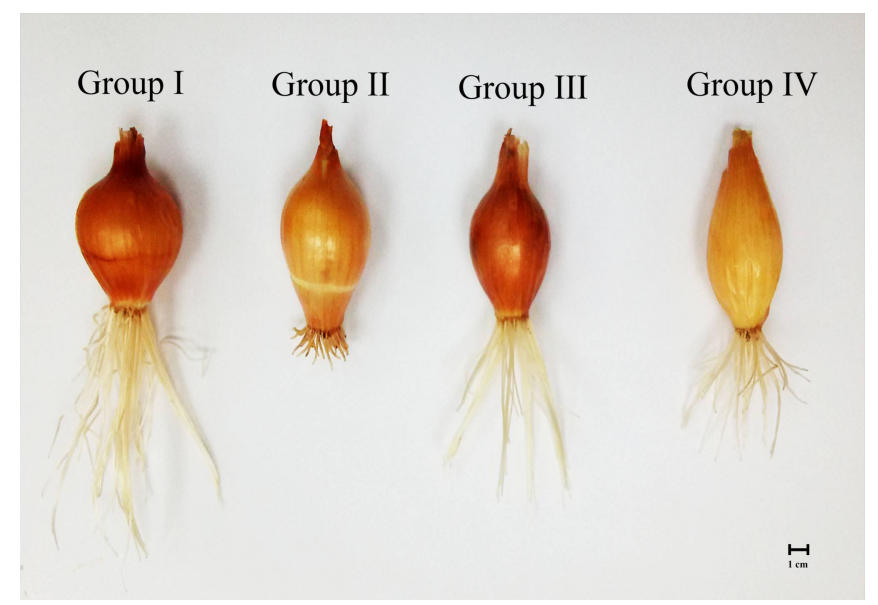

Fig. 1. The germination situations at the end of the $7^{\text {th }}$ day of Allium cepa L. seeds. Group I (control) was treated with distilled water; Group II was treated with $0.225 \mathrm{M} \mathrm{NaCl}$ alone; Group III was treated with $0.1 \% \mathrm{NaClO}$; Group IV was treated with $0.1 \% \mathrm{NaClO}+0.225 \mathrm{M} \mathrm{NaCl}$. Scale bar $=1 \mathrm{~cm}$.

germination and seedling growth under saline conditions until now. Khan and Zia (2007) reported that $10 \% \mathrm{NaClO}$ application significantly showed the negative effect of salt stress on the germination of Limonium stocksii (Boiss) Kuntze seeds. This result is in agreement with the present findings. That $\mathrm{NaClO}$ alleviates salt stress on the seed germination and seedling growth can be understood from the decrease in the salt's osmotic effects. For example, at $0.225 \mathrm{M} \mathrm{NaCl}$ medium, $\mathrm{NaClO}$ application partly increased the fresh weights of the seedlings compared to the control indicates this probability (Table 1). Moreover, it reduced the preventive effect of salt on the seed germination and seedling growth by stimulating mitotic activity of the embryo (Table 2). It could have made a counter-attack against the ABA being a germination inhibitor whose amount probably increases due to the salt existence. 
Some growth regulators may particularly cause mitotic irregularities, cell distortions and chromosomal aberrations even without stress conditions (Tabur and Demir 2010b). So far, there is no reported data relating to effects of $\mathrm{NaClO}$ on the mitotic activity and chromosomal aberrations in non-stress conditions. Therefore, in the present study investigation was carried out to find whether $\mathrm{NaClO}$ is affecting these parameters in normal conditions or not. The data obtained in the present work indicated that the mitotic index in root meristems of A. cepa (group III) seeds exposed to $\mathrm{NaClO}$ application in normal conditions reduced $18 \%$ according to ones of the group I (control) seeds germinated in distilled water. $0.1 \% \mathrm{NaClO}$ application showed a repressive effect on the mitotic activity by slowing down cell division. Moreover, frequency of chromosomal aberrations was increased 46-fold with this dose of $\mathrm{NaClO}$ application. In this case, it may be said that some aberrations may result from this chemical (Table 2).

Table 2. Effect of $\mathrm{NaClO}$ on mitotic index and frequency of chromosomal aberrations in Allium cepa $\mathrm{L}$. root tip meristems.

\begin{tabular}{lcc}
\hline Groups & $\begin{array}{c}\text { Mitotic index } \\
(\%)\end{array}$ & $\begin{array}{c}\text { Chromosome aberration } \\
(\%)\end{array}$ \\
\hline Group I & $* 6.3 \pm 0.2^{\mathrm{c}}$ & $0.0 \pm 0.0^{\mathrm{a}}$ \\
Group II & $3.7 \pm 0.4^{\mathrm{a}}$ & $50.1 \pm 1.0^{\mathrm{d}}$ \\
Group III & $5.2 \pm 1.0^{\mathrm{b}}$ & $46.3 \pm 1.7^{\mathrm{c}}$ \\
Group IV & $9.4 \pm 0.7^{\mathrm{d}}$ & $40.7 \pm 0.4^{\mathrm{b}}$ \\
\hline
\end{tabular}

*The difference between values with the same letter in each column is not significant at $0.05( \pm \mathrm{SD})$. Group I (control) was treated with distilled water; Group II was treated with $0.225 \mathrm{M} \mathrm{NaCl}$ alone; Group III was treated with a $0.1 \% \mathrm{NaClO}$; Group IV was treated with a $0.1 \% \mathrm{NaClO}+0.225 \mathrm{M} \mathrm{NaCl}$.

The cytotoxicity level of a test compound can be determined based on the increase or decrease in the mitotic index (MI), which can be used as a parameter of cytotoxicity in studies of environmental biomonitoring (Fernandes et al. 2007). The inhibitory and cytotoxic effects of salt stress on mitotic activity are known for a long time (Radic et al. 2005, Tabur and Demir 2009, 2010a, b). According to some researchers, high salt concentration causes to total inhibition of mitotic activity and chromosomal abnormalities in root-tip cells (Radic et al. 2005). In the present work, it is observed that salinity adversely affected the mitotic activity and chromosome behaviors in root meristem cells of A. сера. The present data indicated that salinity according to the control decreased $41 \%$ the mitotic index and showed higher number of chromosomal abnormalities. The frequency of aberrations by salinity increased 50 times as compared to the control group. For example, the frequency of chromosomal aberrations in the root tip meristems of the seeds germinated in distilled water was 0.0 while it was 50.1 at $0.225 \mathrm{M}$ salinity. Besides, simultaneous application of $\mathrm{NaClO}+\mathrm{NaCl}$ could be successful in alleviating the negative effect of salinity on the mitotic activity. In addition, simultaneous application of $\mathrm{NaClO}+\mathrm{NaCl}$ showed marked achievement in decreasing the detrimental effect of salinity on the chromosomal aberrations as compared to $\mathrm{NaClO}$ alone. That is, frequency of chromosomal aberrations was approximately decreased $20 \%$ by the simultaneous application (Table 2). These results indicated the repair role of $\mathrm{NaClO}$ against salt injuries during $A$. cepa mitosis.

Normal and abnormal mitotic phases observed during microscopic examination of A. cepa root tip meristem cells were indicated in Figs 2 and 3. The most striking aberrations observed in all applications were micronucleus, irregular prophase, uncoiling chromosome, irregular anaphase, bridge in anaphase, lagging chromosome in anaphase, bridge in telophase, vagrant chromosome in 
telophase and fault polarization in telophase (Fig. 3a-1). The majority of chromosomal abnormalities in root tip cells treated with $\mathrm{NaClO}$ or salt were determined as disorderly prophase (Fig. 3b), uncoiling chromosome (Fig. 3c, d) and fault polarization in telophase (Fig. 31).
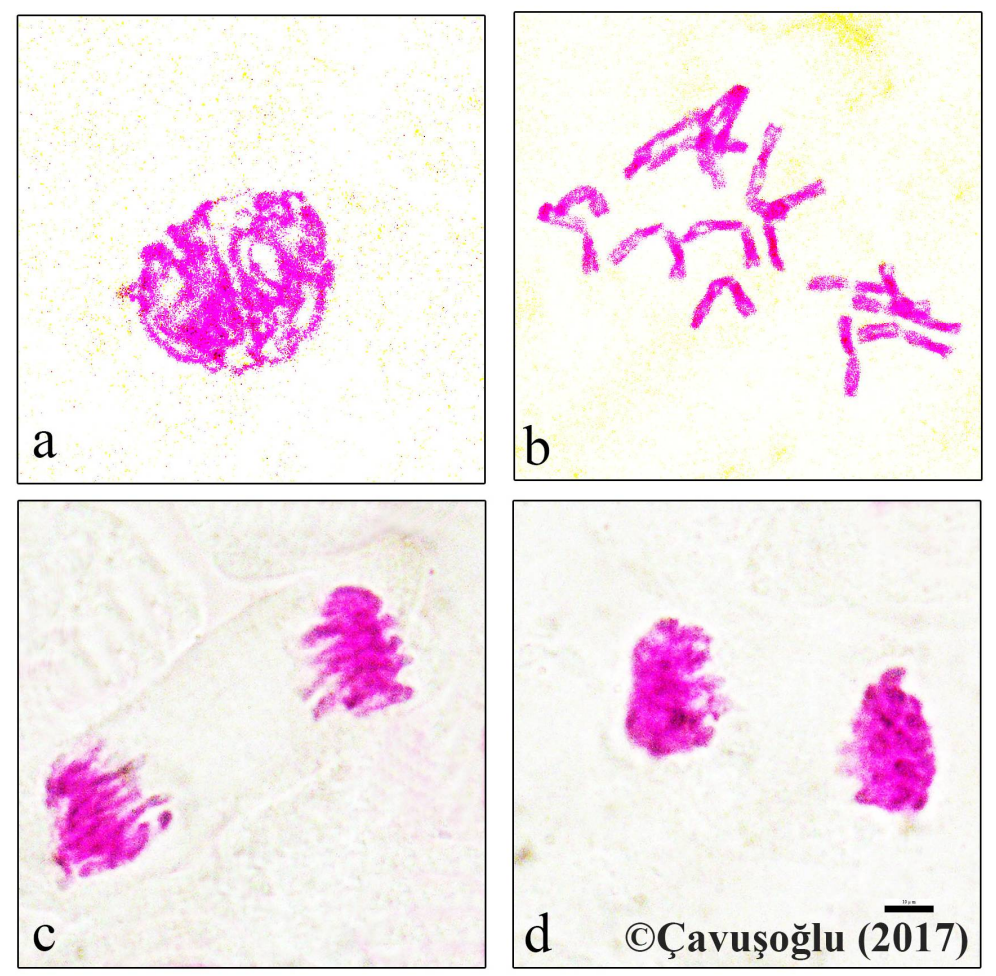

Fig. 2. Normal mitosis phases in root tips meristems of Allium cepa root tip cells. Prophase (a), metaphase (b), anaphase (c) and telophase (d). Scale bar $=10 \mu \mathrm{m}$.

In general, accurate chromosome segregation in mitosis requires that sister kinetochores attach to microtubules emanating from opposite spindle poles. Because kinetochore attachment is a stochastic process, it is error prone and can result in chromosome malorientation (Rieder and Salmon 1998). Mitotic irregularities such as disorderly prophase and anaphase, fault polarization, alignment anaphase, vagrant chromosomes and bridges may be mainly the result from mentioned reasons or spindle dysfunction and constitute a significant portion of chromosomal aberrations. The formations of micronucleus are likely the consequence of vagrant chromosomes and fragments (Briand and Kapoor 1989). The lagging chromosomes are presumably the result of a weak mitotic effect. $\mathrm{NaCl}$ may lead to the highest number of laggards. According to Fiskesjö (1997), $\mathrm{NaCl}$ caused c-mitotic effects including lagging chromosomes. Sticky chromosomes may result from improper folding of the chromatin fibres (Klasterska et al. 1976). It was previously reported that the stickiness reflects highly toxic effect on chromatin (Fiskesjo and Levan 1993). The prophase and metaphase cells with uncoiled chromosomes may be the result of disorderly chromosome contractions. Also, anaphase and telophase bridges could be the result of inversions (Tabur and Demir 2010b). 


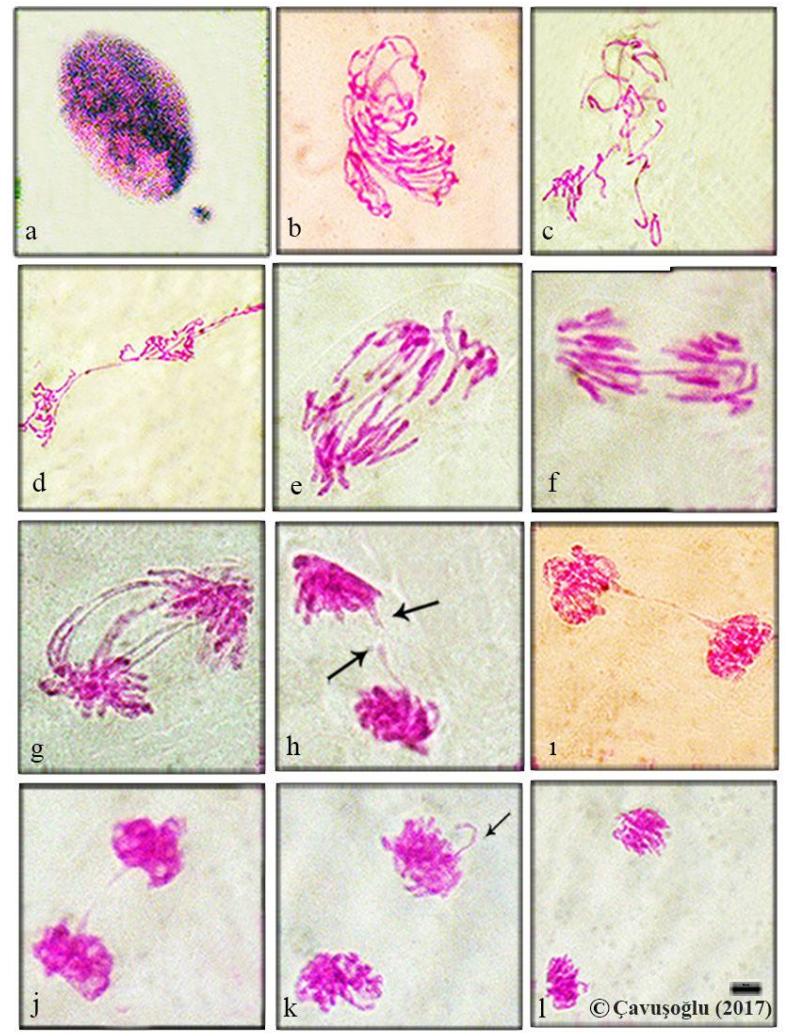

Fig. 3. Chromosomal aberrations examined in mitotic phases of Allium cepa root tip cells. Micronucleus (a), irregular prophase (b), uncoiling chromosome (c, d), irregular anaphase (e), bridge in anaphase (f, g), lagging chromosome in anaphase $(\mathrm{h})$, bridge in telophase $(\mathrm{i}, \mathrm{j})$, vagrant chromosome in telophase $(\mathrm{k})$ and fault polarization in telophase (l). Scale bar $=10 \mu \mathrm{m}$.

Reported data related to effects of $\mathrm{NaClO}$ application in saline conditions on the physiological and cytogenetical parameters are not available. Therefore, the present results in the present work are the first time report particularly in saline conditions. Consequently, this study indicates that $\mathrm{NaClO}$ may significantly improve the activations such as the seed germination, seedling growth and mitotic activity in saline conditions. However, the mechanisms by which salinity inhibits growth are complex and controversial. Moreover, they may vary according to species and cultivar. A universal mechanism has not been established yet. Although the causes of salinity have been characterized, understanding of the mechanisms by which salinity prevents plant growth is still rather poor. Therefore, further studies should be carried out in order to gain more knowledge about effect of $\mathrm{NaClO}$ on molecular metabolism of germination, cell division and cell cycle. This work may serve to provide new conceptual tools for designing hypotheses of salt tolerance in plants.

\section{References}

An P, Inanaga S, Li X, Schimizu H and Tanimoto E 2003. Root characteristics in salt tolerance. Root Res. 12: $125-132$.

Bewley JD and Black M 1994. Seeds: Physiology of Development and Germination. Plenum Press, New York. 445 pp. 
Briand CH and Kapoor BM 1989. The cytogenetic effects of sodium salicylate on the root meristem cells of Allium sativum L. Cytologia 54: 203-209.

Fao 2015. Fao land and plant nutrition management. Available at: http:www.fao.org/ag/agl/agll/spush (Accessed: 20 February 2018).

Fernandes TCC, Mazzeo DEC and Marin-Morales MA 2007. Mechanism of micronuclei formation in polyploidizated cells of Allium cepa exposed to trifluralin herbicide. Pest. Biochem. Physiol. 88: 252-259.

Fiskesjö G 1997. Allium test for screening chemicals; evaluation of cytological parameters. In: Plant for environmental studies, Wang W, Gorsuch JW and Hughes JS (Eds), pp. 308-333. Lewis Publishers, New York.

Fiskesjö G and Levan A 1993. Evaluation of the first ten MEIC chemicals in the Allium test. Altern. Lab. Anim. 21: 139-149.

Ilahi I and Hussain F 1988. Germination improvement of Reptonia buxifolia (Falc.) A. DC., with physicochemical factors. Pakistan J. Forest. 38: 69-78.

Khan MA and Zia S 2007. Alleviation of salinity effects by sodium hypochlorite on seed germination of Limonium Stocksii. Pakistan J. Bot. 39: 503-511.

Klasterska I, Natarajan AT and Ramel C 1976. An interpretation of the origin of subchromatid aberrations and chromosome stickiness as a category of chromatid aberrations. Hereditas 83: 153-162.

Mendes de Jesus VA, Araujo EF, Neves AA, Santos FL, Dias LAS and Ferreira da Silva R 2016. Ratio of seeds and sodium hypochlorite solution on the germination process of papaya seeds. J. Seed Sci. 38: 5761.

Nwangburuka CC, Oyekale K, Ezekiel CN, Anokwuru PC and Badaru O 2012. Effects of Moringa oleifera leaf extract and sodium hypochlorite seed pretreatment on seed germination, seedling growth rate and fungal abundance in two accessions of Abelmoschus esculentus (L) Moench. Arch. Appl. Sci. Res. 4: 875-881.

Radic S, Prolic M, Pavlica M and Pevalek-Kozlina B 2005. Cytogenetic effects of osmotic stress on the root meristem cells of Centaurea ragusina L. Environ. Exp. Bot. 54: 213-218.

Rieder CL and Salmon ED 1998. The vertebrate cell kinetochore and its roles during mitosis. Trends Cell Biol. 8: 310-318.

Sairam RK and Tyagi A 2004. Physiology and molecular biology of salinity stress tolerance in plants. Curr. Sci. 86: 407-721.

Tabur S and Demir K 2009. Cytogenetic response of 24-epibrassinolide on the root meristem cells of barley seeds under salinity. Plant Growth Regul. 58: 119-123.

Tabur S and Demir K 2010a. Role of some growth regulators on cytogenetic activity of barley under salt stress. Plant Growth Regul. 60: 99-104.

Tabur S and Demir K 2010b. Protective roles of exogenous polyamines on chromosomal aberrations in Hordeum vulgare exposed to salinity. Biologia 65: 947-953.

Varasteh KN, Babaei A and Abdoli M 2015. The effect of different sodium hypochlorite concentrations on seed germination of Dracocephalum moldavica L. Austin J. Plant Biol. 1: 1007-1010.

Vujanovic V, St-Arnaud M, Barabe D and Thieault M 2000. Viability testing of orchid seed and the promotion of colouration and germination. Ann. Bot. 86: 79-86. 